\title{
Peningkatan Hasil Belajar IPA Melalui Metode SQ3R pada Siswa SMP Negeri 1 Selesai Tahun Ajaran 2017-2018
}

\author{
Elias Sinaga \\ SMP Negeri 1 Selesai, Kabupaten Langkat, Sumatera Utara, Indonesia \\ Email: Eliassinaga@gmail.com
}

\begin{abstract}
Abstrak
Tujuan dalam penelitian ini adalah untuk meningkatkan hasil belajar IPA melalui metode SQ3R pada siswa kelas IX-7 SMP Negeri 1 Selesai Tahun Ajaran 2017-2018. Penelitian ini merupakan penelitian tindakan kelas dengan metode penelitian deskriptif kualitatif yang terdiri dari 2 siklus. Dari observasi diketahui bahwa nilai keterampilan berbicara siswa mengalami peningkatan. Hal itu dapat dilihat dari hasil observasi yang diketahui bahwa pada pra-siklus mendapatkan nilai rata-rata $67,91(22,22 \%)$, pada siklus I mendapatkan nilai ratarata $72,77(52,77 \%)$ dan pada siklus II mendapatkan nilai rata-rata $80,13(86,11 \%)$. Selain itu melalui metode SQ3R hasil belajar siswa mengalami peningkatan. Hal ini menunjukkan bahwa siswa lebih paham mengikuti pelajaran IPA dengan mengunakan metode SQ3R.
\end{abstract}

Kata Kunci: metode SQ3R, Hasil Belajar

\section{Abstract}

The purpose of this research is to improve the learning outcomes of science through SQ3R method in the students of class IX-7 SMP Negeri 1 Selesai with academic year 2017-2018. This research is a classroom action research with qualitative descriptive research method consisting of 2 cycles. From the observation, it can be seen that the value of student's speaking skills have been increased. It can be seen from the observation that it is known that in the pre-cycle get an average value of 67.91 (22.22\%), in cycle I, it get an average value of 72.77 (52.77\%) and in cycle II, it get an average value of 80, 13 (86.11\%). In addition through the SQ3R method student learning outcomes was increased. This shows that the students are better understood to follow science lesson by using SQ3R method.

Keywords: SQ3R method, learning outcomes 


\section{A. PENDAhuluan}

Kegiatan belajar mengajar peserta didik ternyata memiliki keunikan yang berbeda-beda antara peserta didik satu dengan peserta didik lainnya. Guru harus memahami karakteristik peserta didikpeserta didiknya dan dapat melakukan pendekatan dalam belajar mengajar sebagai upaya mengoptimalisasikan hasil belajar, sebab tanpa pendekatan ini hasil belajar tidak akan diperoleh dengan sebaikbaiknya. Sementara itu, saat ini masih banyak guru yang dalam kegitan belajar mengajar masih menggunakan cara lama dalam penyampaian materi yaitu dengan metode ceramah. Metode ceramah merupakan metode konvensional yang masih dilakukan oleh guruguru dari dulu hingga sekarang. Metode konvensional ini cukup mudah dilaksanakan oleh guru karena kurang menuntut usaha yang banyak baik guru maupun peserta didik disamping itu metode ceramah kadar keaktifannya rendah.

Berdasarkan hasil observasi diketahui bahwa hasil belajar siswa kelas IX-7 SMP Negeri 1 Selesai Tahun Pelajaran 2017-2018 sangat rendah. Karena metode yang digunakan masih dengan metode ceramah. Selain itu aktivitas belajar siswa juga mengalami penurunan. Siswa tidak tertarik untuk mengikuti pembelajaran IPA karena metode pembelajaran yang digunakan sangat membosankan. Untuk itu peneliti berupaya untuk mengatasi permasalahan tersebut untuk membantu siswa tersebut meningkatkan hasil belajar IPA agar memenuhi nilai KKM yang telah ditetapkan oleh pihak sekolah 75 serta untuk meningkatkan aktivits belajar siswa. Salah satu alternatif metode yang dapat diterapkan adalah SQ3R (Survey, Question, Read, Retice, Review), yaitu pembelajaran yang dirancang khusus untuk memahami suatu konsep yang merupakan variasi dalam proses pembelajaran khususnya pembelajaran biologi.

Pada artikel ini dipaparkan peningkatan hasil belajar IPA serta peningkatan aktivitas belajar pada siswa kelas IX-7 SMP Negeri 1 Selesai Tahun Pelajaran 2017-2018.

\section{B. METODE SURVEY, QUESTION, READ, RETICE, REVIEW (SQ3R)}

SQ3R merupakan metode pembelajaran yang bersifat praktis dan dapat diaplikasikan dalam berbagai pendekatan belajar (Robinson, 
(1978). Para prinsipnya, SQ3R merupakan singkatan langkah-langkah pokok kajian yang meliputi:

1) Survey, artinya mengidendentifikasi seluruh teks.

2) Question, artinya menyusun daftar pertanyaan yang relevan dengan teks.

3) Read, artinya membaca teks untuk mencari jawaban atas pertanyaan yang telah disusun.

4) Retice, artinya menghafalkan dari setiap jawaban atas pertanyaan yang telah ditemukan.

5) Review, artinya meninjau ulang seluruh jawaban atas pertanyaan yang telah disusun.

SQ3R merupakan metode pembelajaran yang dapat membantu peningkatan hasil belajar siswa, karena ia mempunyai peranan dan manfaat sebagai berikut:

\section{Peranan SQ3R adalah:}

- Merupakan variasi pembelajaran.

- Memudahkan mengajar, karena dengan SQ3R pembelajaran tersusun sesuai dengan urutan atau langkah-langkah yang jelas.

- Meningkatkan kreativitas keterlibatan siswa secara langsung dalam kegiatan belajar mengajar.

- Dapat memudahkan siswa dalam belajar, karena dengan menggunakan metode ini siswa menjadi aktif membaca dan langsung terarah pada intisari kandungan-kandungan pokok yang tersirat dan tersurat dalam pokok kajian/konsep atau bacaan.

\section{Manfaat SQ3R dalam meningkatkan proses belajar}

- Siswa lebih aktif dan berkonsentrasi dalam belajar.

- Siswa lebih mudah memahami isi pada setiap konsep pokok bahasan atau sub konsep bahasan yang dipelajari

- Siswa mampu mempelajari setiap materi pelajaran tanpa menggantungkan bantuan orang lain.

- Siswa dapat lebih memahami materi pelajaran dalam waktu yang lebih singkat.

- Siswa dapat lebih mengingat hal-hal yang dianggap penting.

- Hasil belajar siswa akan dapat lebih meningkat.

- Guru lebih mudah mengawasi kegiatan belajar siswa.

- Suasana kelas lebih tenang dan tertib. 


\section{Kelemahan SQ3R}

Beberapa kelemahan SQ3R, antara lain:

- Pelaksanaan SQ3R dalam langkah-langkahnya memerlukan keterampilan mencari kata penting, keterampilan membuat pertanyaan yang tidak dimiliki oleh siswa.

- SQ3R hanya menekankan pada pemahaman isi bacaan atau materi pelajaran sehingga dalam pembelajaran IPA yang memerlukan pengamatan perlu dilengkapi dengan alat bantu lain (seperti praktikum).

\section{METODE PENELITIAN}

Penelitian ini dilakukan dilakukan di SMP Negeri 1 Selesai dengan jumlah siswa sebanyak 27 orang. Karateristik siswa tesebut adalah daya ingat siswa terhadap pembelajaran IPA masih sama dengan siswa dari kelas lain. Metode penelitian yang digunakan adalah Penelitan Tindakan Kelas (PTK) yang terdiri dari 2 siklus meliputi: perencanaan, pelaksanaan tindakan, observasi dan evaluasi serta refleksi.

Prosedur penelitian adalah rencana yang disusun oleh peneliti untuk menemukan jawaban dalam pertanyaan-pertanyaan penelitiannya. Dalam penelitian ini, rencana yang disusun oleh peneliti bertujuan untuk menerapkan metode pembelajaran SQ3R untuk meningkatkan hasil belajar IPA pada siswa SMP 1 Selesai Tahun Ajaran 2017-2018.

Teknik pengumpulan data melalui, observasi dan melakukan tes untuk memperoleh data yaitu hasil belajar setiap akhir tindakan untuk mengukur pemahaman siswa terhadap materi. Data hasil pengamatan dan tes diolah dengan analisis deskriptif untuk menggambarkan keadaan peningkatan pencapaian keberhasilan tiap siklus dan untuk menggambarkan keberhasilan pembelajaran dengan metode pembelajaran SQ3R. intikator keberhasilan ditentukan dapat tercapai $80 \%$ siswa SMP mendapatkan nilai 75 .

\section{HASIL DAN PEMBAHASAN \\ 1. Hasil Penelitian}

Hasil penelitian ini diperoleh dari hasil tes belajar dan hasil observasi terhadap aktivitas belajar siswa pada siklus I dan siklus II. Pada kondisi awal, hasil belajar siswa SMP Negeri 1 Selesai masih 
sangat rendah, dimana nilai rata-rata yang diperoleh hanya mencapai 67,91 sementara nilai KKM ynag ditetapkan oleh pihak sekolah sebesar 75. Jumlah siswa yang tuntas belajar hanya 8 orang atau $22.22 \%$. Hasil belajar pada siklus I mengalami peningkatan setelah diberikannya tindakan, hal itu diketahui dari perolehan nilai rata-rata yang diperoleh mencapai 72,77 . Selain itu jumlah siswa yang tuntas belajar mengalami peningkatan dari 8 orang menjadi 19 orang atau $52,77 \%$. Kemudian lakukan siklus II, hasil belajar semakin meningkat, hal itu diketahui dari perolehan nilai rata-rata yang diperoleh mencapai 80,13 . Selain itu jumlah yang tuntas belajar semakin meningkat dari 19 orang menjadi 31 orang atau $86,11 \%$. Melihat hasil yang sudah sesuai harapan maka peneliti merasa tidak perlu untuk melanjutkan penelitian kesiklus berikutnya.

Aktivitas belajar siswa SMP Negeri 1 Selesai pada kondisi awal masih sangat kurang. Hal itu terlihat dari jumlah skor yang berhasil diperoleh hanya 7 dengan kategori kurang. Sedangkan pada siklus I, aktivitas belajar siswa mengalami peningkatan. Meskipun kategori yang didapat masih kurang, namun jumlah nilai skor yang diperoleh bertambah menjadi 10. Pada siklus II jumlah skor yang diperoleh mencapai 12 dengan kategori cukup. Seterusnya, dilakukan tindakan, jumlah skor yang diperoleh mencapai 18 dengan kategori baik. Melihat hasil yang sudah sesuai dengan harapan, maka peneliti merasa tidak perlu melanjutkan penelitiannya kesiklus berikutnya.

\section{Pembahasan}

Berdasarkan dari hasil observasi awal diektahui bahwa hasil belajar IPA Biologi siswa SMP Negeri 1 Selesai Tahun Ajaran 20172018. hal itu dikarenakan banyaknya bahasa latin yag digunakan membuat siswa tidak mengerti selain itu metode yang digunakan masih konvensional sehingga siswa malas untuk mengikuti pembelajaran IPA Biologi. Peneliti menerapkan metode SQ3R untuk membantu siswa SMP tersebut. Setelah diterapkan metode SQ3R diketahui hasil belajar siswa SMP Negeri 1 Selesai mengalami peningkatan disetiap siklusnya. Selain hasil belajar aktivitas belajar siswa juga mengalami peningkatan. Hal ini membuktikan bahwa melalui metode SQ3R siswa tertarik untuk mengikuti pembelajaran IPA Biologi. 


\section{E. SIMPULAN}

1. Kesimpulan

Berdasarkan data yang diperoleh dalam penelitian ini dapat ditarik kesimpulan bahwa melalui SQ3R dapat meningkatkan hasil belajar IPA Biologi pada siswa kelas IX-7 SMP Negeri 1 Selesai Tahun Pelajaran 2017-2018. Simpulan ini berdasarkan observasi bahwa:

a. Pembelajaran melalui SQ3R akan membantu siswa kelas IX-7 SMP Negeri 1 Selesai Tahun Pelajaran 2017-2018 dalam meningkatkan hasil belajar.

b. Hasil penelitian menunjukkan bahwa hasil belajar sebelum diberikan hanya memperoleh nilai rata-rata 6791. Setelah dilakukan tindakan pembelajaran dengan SQ3R diperoleh rata-rata nilai hasil belajar pada siklus I sebesar 72,77, Sedangkan pada siklus II diperoleh nilai rata-rata 80,13.

c. Hasil penelitian menunjukkan bahwa persentase ketuntasan belajar siswa juga meningkat disetiap siklus. Diketahui pada pra-siklus diketahui bahwa persentase ketuntasan belajar siswa hanya mencapai $22.22 \%$, pada siklus I mencapai $52,77 \%$ dan pada siklus II mencapai $86,11 \%$.

\section{Saran}

Sehubungan dengan simpulan penelitian ini, peneliti mengemukakan saran kepadaguru Bahasa Indonesiasebagai berikut :

a. Untuk meningkatkan hasil belajar IPA Biologi menggunakan SQ3R dapat dijadikan sebagai salah satu altenatif guru dalam melakukan kegiatan pembelajaran di kelas.

b. Guru dalam mendidik siswa harus lebih sabar dan mengarahkan siswa dalam proses pembelajaran agar siswa aktif, disiplin, dan mengerjakan tugas dengan penuh rasa tanggung jawab.

c. Setelah siswa melakukan tes, hendaknya guru memberikan komentar tentang kekurangan dan kelebihan siswa.

\section{F. DAFTAR PUSTAKA}

Robinson, 1978. Effective Study. New York: Harper and Brother Publishers. 
JURNAL TABULARASA PPS UNIMED, Vol.15 No.1, April 2018 p-ISSN: 1693-7732, e-ISSN: 2502-7247 http://jurnal.unimed.ac.id/2012/index.php/tabularasa

Darsono, Maks. 2001. Belajar dan Pembelajaran. Jakarta: Rineka Cipta.

Hamalik, Oe. 1997. Proses Belajar Mengajar. Jakarta: Bumi Aksara.

Sudjana, N. 2002. Penilaian Hasil Proses Belajar Mengajar. Bandung: Remaja Rosdakarya.

Slameto. 1998. Belajar dan Fakto-faktor yang Mempengaruhinya. Jakarta: Rineka Cipta. 